\title{
Development of E-Learning with Whiteboard Animation Media Using Reading, Questioning Model and Answering (RQA) to Improve Learning Results and Student Motivation in the Department of Tadris Biology in IAIN Batusangkar
}

\author{
Dinia Anjelina ${ }^{1}$, Violita $^{2}$ \\ ${ }^{1,2}$ Master of Biology Education, Padang State University, Padang, Indonesia
}

\begin{abstract}
Based on preliminary investigation data by interviewing animal structure lecturers and students from IAIN Batusangkar, it is known that there are obstacles in animal structure lectures, one of which is related to the learning media used, so students have difficulty understanding lecture material. The difficulty felt by students was that almost every animal structure material was difficult to understand, especially the reproductive system material so students had difficulty illustrating images on the reproductive system material. This study aims to produce whiteboard animation learning media using the RQA model on valid, practical, and effective reproductive system materials. This type of research is development research using the plomp model which consists of three phases, namely the preliminary research phase, the design and prototyping phase, and the assessment phase. The research data were obtained from validity, practicality, and effectiveness tests. The results obtained in this study, namely the results of validation by the validator showed a value of $87.85 \%$ with very valid criteria. The results of the practicality assessment by the lecturers showed a value of $93.50 \%$ with very practical criteria and the results of the practicality assessment by students getting a score of $89.58 \%$ with very practical criteria. The results of the effectiveness test showed a significant increase in the learning outcomes of the knowledge aspect and could increase students' learning motivation. Based on the values obtained, it can be concluded that the whiteboard animation media using the RQA model on the reproductive system material is very valid, very practical, and very effective to use in the learning process.
\end{abstract}

KEYWORDS: Development, RQA Model and Motivation, Whiteboard Animation.

\section{INTRODUCTION}

The development of technology and science is increasingly rapidly pushing for renewal efforts in the use of technology in the learning process. The current learning process needs to be supported by technology-based learning media. Technology-based media can make students adapt to the flow of technological developments and indirectly develop the quality of their human resources. One of the technology-based media that can support the learning process is in the form of e-Learning. E-Learning is one of the technology-based learning media that can be used as a means for the learning process without having to meet face-to-face between lecturers and students.

E-Learning will make learning easier, more practical, and flexible so that the learning process carried out will be maximized. ELearning has many advantages compared to traditional learning, namely the availability of very broad and free content, no transportation costs, no stationery costs, and flexible time to study. This is supported by the opinion of Prasojo (2011) that four benefits can be obtained in the use of e-Learning, namely personal experience in learning, reducing costs, ease to achieve, and the ability to be responsible. The use of E-learning is very helpful, especially during the Covid-19 conditions that require social distancing so that the lecture process is carried out online, one of which is in the Animal Structure course.

The Animal Structure course is the main basic course in studying Structure, Anatomy, Embryogenesis, Morphogenesis, Organogenesis, Regeneration, and in vitro culture methods of vertebrate animal body development. Animal structure courses in universities are taught with a theoretical learning system in class with a Semester Credit Unit (SKS) weight of 2 credits.

There are still some problems in the learning process that has been carried out by students. Based on observations that have been made at IAIN Batusangkar, especially Tadris Biology, technology-based learning has not been implemented optimally before Covid- 


\section{International Journal of Current Science Research and Review}

ISSN: 2581-8341

Volume 05 Issue 02 February 2022

DOI: 10.47191/ijcsrr/V5-i2-36, Impact Factor: 5.825

IJCSRR@ 2022

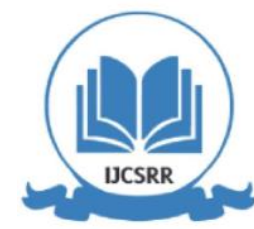

www.ijcsrr.org

19, but the development of e-learning during the Covid-19 period is very helpful for the lecture process because all lecture activities are carried out online through the platform. E-learning.

The above relates to an interview conducted with one of the biology lecturers at IAIN Batusangkar, namely Mrs. Roza Helmita, M.Si on June 30, 2021, that during the Covid-19 pandemic, students conducted lectures through online platforms, such as zoom, google form, quiz, e-campus, and others. In the learning process, teaching materials are in the form of modules and use the group discussion method, due to limited learning time through online platforms so that students do not understand the material presented. One of the obstacles faced during online lectures is learning motivation. Student learning motivation is low as evidenced by the activeness of students during discussions, only a few people are actively involved in the learning process. Motivation is very important to encourage students to act, determine the direction of action, namely towards the goals to be achieved and select the actions that must be done. Learning outcomes will be optimal if there is motivation. The more precise the motivation is given, the more successful the learning will be (Sardiman, 2011). This should be a concern and evaluation for lecturers in the learning process. Based on the results of the questionnaire given to students, it was found that $72.9 \%$ of students had difficulty learning the material of the reproductive system. The results of the questionnaire also showed that as many as $100 \%$ of students used textbooks to study this material. Furthermore, as many as $52.1 \%$ of students revealed that they were not able to understand this material just by reading explanations through textbooks.

Based on interviews with students, the problems during lectures are first, during online lectures the teaching materials used in the form of modules have not made it easier for students to understand the material as a whole. Second, the limitations of students are constrained in translating the material obtained from Google which is broad in scope and not by the learning objectives, this proves that students are less motivated to learn the material from various learning sources. Third, students do not have independent learning. This will result in students attending lectures just wanting to know without paying attention to their learning outcomes. Fourth, students have different learning styles, most students have audiovisual and kinesthetic learning styles. Fifth, in online lectures, the explanation of the material delivered is too fast, making it difficult to understand. The explanation above shows the lack of variety of learning media used to help the learning process that can improve student understanding.

According to Smaldino (2011) learning media has a role in delivering available material by involving technology and surveying source and media reference guides by changing existing materials and designing new materials. Therefore, lecturers must be able to determine and develop learning media to make it easier to transfer material to students.

Learning media has an important role in the teaching and learning process, in these activities material that is not clearly understood by students can be assisted in its delivery by using media as a tool. Learning media can facilitate what the lecturers are unable to convey through explanations so that students can understand the material more easily than without using learning media.

Media is a tool that is needed by lecturers in creating a good learning process. A good learning process is one of the determinants of the success of the teaching and learning process. Media is anything that can be used to transmit messages from sender to receiver so that it can stimulate the thoughts, feelings, interests, and attention of students (Sadiman, 2009). Learning media is intended to assist lecturers in sending messages, information, or subject matter to students. So that it can make it easier for students to understand the subject matter.

These problems can be overcome with innovations in learning media. One form of visual media that can be a solution is video media which is equipped with explanations through whiteboard animation media using the Reading, Questioning, and Answering (RQA) Model with a variety of interesting colors and shapes.

In a learning process, two main elements are very important, namely the learning model and learning media. The model or pattern of lectures is a major aspect of the educational process in higher education. According to Bahri (2016), the RQA learning model is considered a learning model based on constructivism learning theory. This learning model was developed based on the fact that almost all students who are assigned to read lecture materials related to upcoming lectures always do not read, which results in the designed lecture strategies being difficult or not implemented and in the end understanding of the lecture material is low or even very low. Then according to Tendrita and Sari (2020) the implementation of the RQA learning model can familiarize students with reading the assigned course material so that the lecture strategies designed can be implemented and understanding of the lecture material can be improved.

The RQA model process by reading, making questions, and answering them according to the material to be studied is one of the best preparations so that during the learning process in class students are not just silent, because students are assigned to study first 


\section{International Journal of Current Science Research and Review}

ISSN: 2581-8341

Volume 05 Issue 02 February 2022

DOI: 10.47191/ijesrr/V5-i2-36, Impact Factor: 5.825

IJCSRR@ 2022

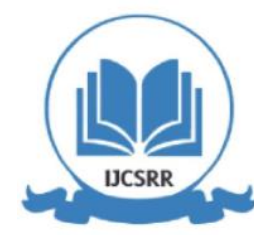

www.ijcsrr.org

(Bachtiar, 2013). Learning with RQA can force students to read the assigned material so that it can support the learning process in the classroom (Corebima, 2009).

Preparation from home will be a provision for the learning process in class so that students have the provision to speak. So that when learning using whiteboard animation media combined with RQA can make students motivated to express opinions and questions in class so that they do not remain silent. Research conducted by Bahri (2016) that RQA learning steps are proven to be effective in improving student cognitive learning outcomes. One of the learning steps in RQA is reading activities.

Whiteboard animation is a video depicting the process of drawing, usually on a whiteboard or something resembling a whiteboard. Unlike traditional animation, whiteboard animation can dynamically represent concepts without focusing on narrative action. Whiteboard animation places students in the role of animator or narrator while drawings are created, perhaps to help students mentally construct concepts. This animation uses rather funny line drawings which can be considered as an emotional design in multimedia instruction (Plass, et al., 2014).

Research on the use of whiteboard animation media has been carried out by many researchers. One of them is a study by Manny, et al., (2011) learning with whiteboard animation media makes students' motivation better, and learning outcomes increase, teachers also further improve their ability to develop learning. According to Akbas \& Pektas (2011) the use of whiteboard animation in learning makes students more enthusiastic in learning, increases student participation rates compared to ordinary learning, and also understands concepts more effectively. Meanwhile, research by Kocak \& Gulcu (2013) states that the use of whiteboard animation by teachers can solve the difficulties experienced by students in receiving lesson materials. Furthermore, according to Pratiwi (2019) the use of whiteboard animation media is very effective for use in the lecture process, besides that this media is also portable, which can be used wherever students are.

According to Gillen, et al., (2008) learning using whiteboard animation media can effectively help lecturers in the process of delivering material. This media uses moving animations accompanied by pictures and descriptions. This media becomes more interesting depending on the creativity of the developer.

Based on the problems that have been disclosed, the researcher has conducted a research "Development of e-learning with whiteboard animation media using the Reading, Questioning, and Answering (RQA) model to improve student learning outcomes and motivation to learn".

\section{RESEARCH METHOD}

This type of research is research and development using the Plomp model. The main stages in the Plomp development model are preliminary research, the development or prototyping phase, and the assessment phase.

Validation is carried out at the development or prototyping phase, which consists of several prototypes, namely:

\section{Prototype I}

The prototype I begin with designing a storyboard for whiteboard animation media using the reading, questioning, and answering (RQA) model based on the results obtained in the preliminary research phase, followed by the manufacture of whiteboard animation media products using the reading, questioning, and answering (RQA) model. ) using the Sparkol Videoscribe program and Camtasia studio 8 . The prototype I was evaluated using self-evaluation, namely by revising the whiteboard animation media based on reading, questioning, and answering (RQA) which had been designed using a checklist to check for errors that might still be found. the prototype was then revised. Furthermore, the prototype II development stage was carried out Prototype II.

\section{Prototype II}

At this stage, consultation with experts (expert review) is carried out to obtain whiteboard animation media using a valid reading, questioning, and answering (RQA) model. Aspects that are validated include aspects of constructs, aspects of content, aspects of graphics, and aspects of language. Subsequently, a one-to-one evaluation was conducted, by asking 3 students with low, medium, and high ability levels to provide comments on the whiteboard animation media using the designed reading, questioning, and answering (RQA) model.

\section{Prototype III}

The development of prototype III is the result of a revision of prototype II. Prototype III was evaluated using a small group evaluation, which was an evaluation of six students of the biology education study program at IAIN Batusangkar who took the 


\section{International Journal of Current Science Research and Review}

ISSN: 2581-8341

Volume 05 Issue 02 February 2022

DOI: 10.47191/ijesrr/V5-i2-36, Impact Factor: 5.825

IJCSRR@ 2022

Animal Structure course for the July-December 2021 period with different abilities (high, medium, and low). ). This small group evaluation was conducted to determine the practicality of the products that have been designed.

\section{Prototype IV}

Prototype IV is the result of a revision of prototype III. Prototype IV will proceed to the assessment phase by conducting a large group trial (field test).

\section{RESULTS AND DISCUSSION}

Results

The results obtained at the initial investigation stage of the preliminary research stage are used as guidelines in developing a whiteboard animation media research using the RQA model. The results of the development at this stage are as follows:

\section{Prototype I}

The prototype I was developed by first designing a storyboard media Whiteboard animation using the Reading, Questioning, and Answering (RQA) model. After that, it was continued by making Whiteboard animation media products using the Reading, Questioning, and Answering (RQA) model using the Sparkol Videoscribe program, Adobe Illustrator 2020, Wave Editor, Audacity, and Camtasia Studio 8.

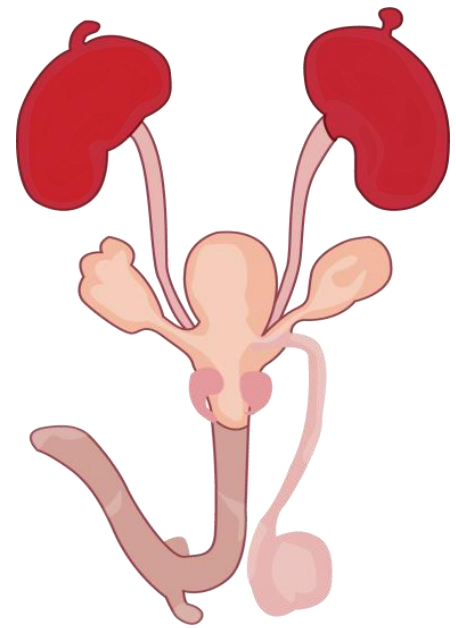

Figure 1. Male mammalian reproductive system

\section{Prototype II}

The prototype II was produced after prototype I was revised, after that, a formative evaluation was carried out in the form of an assessment of the validity of the Whiteboard animation media using the Reading, Questioning, and Answering (RQA) model by three validators. The assessment consists of four aspects, namely construct, content, graphics, and language. The assessment instrument used was a questionnaire on the validity of the Whiteboard animation media using the Reading, Questioning, and Answering (RQA) model. The results of the validation of the Whiteboard animation media using the Reading, Questioning, and Answering (RQA) model can be seen in Table 1.

Table 1. The results of the validation of the Whiteboard animation media using the Reading, Questioning and Answering (RQA) Model by the validator

\begin{tabular}{llll}
\hline No & Rated aspect & Value Validity & Criteria \\
\hline 1 & Constructive aspect & 87,50 & Very Valid \\
2 & Content aspect & 88,89 & Very Valid \\
3 & Graphic aspect & 83,33 & Very Valid \\
4 & Language aspect & 91,67 & Very Valid \\
Average & 87,85 & Very Valid \\
\hline
\end{tabular}




\section{International Journal of Current Science Research and Review}

ISSN: 2581-8341

\section{Volume 05 Issue 02 February 2022}

DOI: 10.47191/ijesrr/V5-i2-36, Impact Factor: 5.825

IJCSRR@ 2022

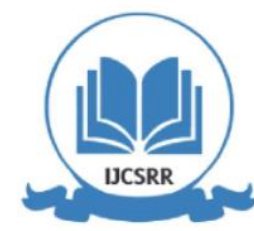

www.ijesrr.org

Based on Table 1, it can be seen that the aspects of construction, content, graphics, and language have met the very valid category. This criterion is obtained by looking at the indicators that can be met by the Whiteboard animation media using the Reading, Questioning, and Answering (RQA) model. So that this media based on the validator's assessment is feasible to use.

After that, a one-to-one evaluation was carried out, it was found that all the indicators needed in the Whiteboard animation media using the Reading, Questioning, and Answering (RQA) model already existed. Students think that the material is easy to understand and systematically arranged, the language used is easy to understand, easy to understand, and quite clear, the media display is good and attractive and the pictures are clear so that it can make it easier for students to understand the material.

\section{Prototype III}

At this stage, a small group evaluation was conducted on six students by looking at the practicality of the Whiteboard animation media using the developed Reading, Questioning, and Answering (RQA) Model. The results of the small group practicality data analysis can be seen in more detail in Table 2.

Table 2. Practical Test Results of Whiteboard animation media using the Reading, Questioning and Answering (RQA) Model by Students in Small Groups

\begin{tabular}{|c|c|c|c|}
\hline No & Assessment Aspect & Average Score (\%) & Category \\
\hline 1 & Ease of use & 83,88 & Very practical \\
\hline 2 & Time efficiency & 81,25 & Very practical \\
\hline 3 & Benefit & 81,25 & Very practical \\
\hline Total & & 81,94 & Very practical \\
\hline
\end{tabular}

Based on the data in Table 2, it is known that the value of the practical aspect of the six students in the criteria is very practical. Based on these results, the Whiteboard animation media using the Reading, Questioning, and Answering (RQA) model on the reproductive system material is practically used by students in terms of ease of use, time efficiency, and benefits.

\section{Prototype IV}

Data at the assessment stage were obtained from practical tests by lecturers and students in large groups (Field Test), then an effectiveness test was carried out covering learning outcomes and motivation.

\section{DISCUSSION}

Whiteboard animation is an animated video learning media that consists of a series of images arranged into a complete video. With unique characteristics, whiteboard animation can present learning content by combining images, sounds, and attractive designs so that students can enjoy the learning process (Hasan, 2019). This media is combined with the Reading, Answering, and Questioning (RQA) Model so that students better understand the learning material conveyed in the media. This is supported by the opinion of Darussyamsu and Fadilah (2017) that the implementation of the RQA learning model is proven to be able to force students to read the assigned course material, so that the lecture model designed can be implemented and understanding of the lecture material has been successfully improved by almost $100 \%$. Whiteboard animation media using the Reading, Questioning, and Answering (RQA) model that was developed can help students understand the Reproductive System material because it contains images, audio, material, and others so that it is easier to understand.

The whiteboard animation media using the RQA model was declared very valid after being assessed by the validator, the validity assessment was seen from several aspects, namely the constructed aspect, content aspect, graphic aspect, and language aspect.

The validity of the whiteboard animation media using the Reading, Questioning and Answering (RQA) model which was carried out by three validators in terms of construct, content, graphics, and language aspects with a score of $87.85 \%$ very valid criteria. According to Arikunto (2013) that if the data generated from a product is valid, then it is said that the product has provided an overview of the development objectives correctly and by the reality and actual conditions.

The whiteboard animation media using the Reading, Questioning, and Answering (RQA) model was declared very valid by the validator from the constructed aspect with a score of $87.50 \%$. Whiteboard animation media using the Reading, Questioning, and Answering (RQA) model is designed to be used in the form of videos that run without using a data package so that students can access the videos whenever and wherever they need. This is in Pratiwi's opinion (2019) that whiteboard animation media is portable, that is, it can be studied wherever students are. 


\title{
International Journal of Current Science Research and Review
}

\author{
ISSN: 2581-8341
}

\section{Volume 05 Issue 02 February 2022}

DOI: 10.47191/ijcsrr/V5-i2-36, Impact Factor: 5.825

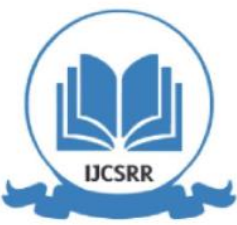

www.ijesrr.org

In the aspect of whiteboard animation media content using the Reading, Questioning, and Answering (RQA) model, the validator stated that it was very valid with a score of $88.89 \%$. The content aspect contains material about the Reproductive System. This material was chosen according to the learning outcomes that exist at the university. Overall this material contains reproductive structures invertebrates that are difficult for students to understand. The development of whiteboard animation media using the Reading, Questioning, and Answering (RQA) model aims to visualize the image so that students can see in more detail the reproductive structure of vertebrates so that it can help students understand the material. This is in Hasan's opinion (2019), the characteristics of video scribe media in learning include audio-visual media which have advantages including being able to focus students' attention during learning activities so that messages can be conveyed more effectively, able to provide a good stimulus for students, can be repeated. (reinforcement), clarifying abstract things and providing more realistic explanations, as well as messages conveyed quickly and easier to remember, and able to combine text, images, audio, music, and images in a single unit so that learning objectives can be achieved.

The assessment of the graphic aspect assessed by the expert was declared very valid with a score of $83.33 \%$. This means that the components on the whiteboard animation media using the Reading, Questioning, and Answering (RQA) model in the form of images, animations, audio, writing, and designs have been fulfilled properly. This is in Najahah's opinion (2020) that whiteboard animation is a communication medium that contains words, sentences accompanied by pictures, and audio that will help the recipient easily understand what the sender wants to convey.

The result of the next validation is the language aspect and the score is very valid with a score of $91.67 \%$. This means that the whiteboard animation media using the Reading, Questioning, and Answering (RQA) model that has been developed is good and correct by the Indonesian Spelling (EBI). This is by the opinion of Muslich (2007) the criteria for good language eligibility include (1) the suitability of the use of language with the intellectual, social and emotional development of the reader, (2) the use of communicative language, the indicators are message readability and the determination of linguistic rules, and (3) coherence and coherence in the flow of thought, the indicators are coherence and coherence between sections and paragraphs.

The whiteboard animation media assessment uses the Reading, Questioning, and Answering (RQA) model at the practical stage by lecturers who are assessed from the aspect of ease of use, learning time efficiency, and benefits in the very practical category with a score of $93.5 \%$. This is by the research of Wibowo and Matona (2019) that Whiteboard animation media is practically used in learning.

Data on the practicality of whiteboard animation using the Reading, Questioning, and Answering (RQA) model, which was carried out on students, obtained a score with very practical criteria with a score of $89.58 \%$. This means that the whiteboard animation media using the Reading, Questioning, and Answering (RQA) model is easy for students to use in lectures. According to Gillen, et.al., (2008) learning using whiteboard animation media can effectively help teachers in the process of delivering material.

The results of hypothesis testing conducted on posttest scores in the experimental and control classes also showed that there was a significant difference between student learning outcomes in the two classes. This shows that the whiteboard animation media using the Reading, Questioning, and Answering (RQA) model in the learning process has a positive impact on improving student learning outcomes (cognitive aspects). According to Sakat, et.al., (2012) learning using technology media has a significant influence on learning.

Based on the motivational questionnaire filled out by students, it was found that the use of whiteboard animation media using the Reading, Questioning, and Answering (RQA) model greatly motivates students in the learning process. Students also responded that learning to use whiteboard animation using the Reading, Questioning, and Answering (RQA) model was very fun and motivated students during the learning process. According to Manny, et.al., (2011) learning with interactive whiteboard media makes students' motivation better and learning outcomes increase, teachers also increase their ability to develop learning. The implementation of the RQA model that the researchers developed using video whiteboard animation can also increase students' learning motivation. This is by the opinion of Bahri (2016) who stated that the questions in the RQA step can motivate students, help students think coherently, find interests, train to express something, develop thinking skills, and so on.

\section{CONCLUSIONS}

Based on the results of the research that has been done, it can be concluded that whiteboard animation media has been produced using the Reading, Questioning, and Answering (RQA) model with valid, practical, and effective criteria. 


\section{International Journal of Current Science Research and Review}

ISSN: 2581-8341

Volume 05 Issue 02 February 2022

DOI: 10.47191/ijesrr/V5-i2-36, Impact Factor: 5.825

IJCSRR@ 2022

www.ijesrr.org

\section{REFERENCES}

1. Akbas, O., \& Pektas, H. M. 2011. The effects of using an interactive whiteboard on the academic achievement of university students. In Asia - Pacific Forum on Science Learning and Teaching. 12: 1 - 19.

2. Arikunto, S. 2013. Dasar-Dasar Evaluasi Pendidikan (Edisi 2). Jakarta: Bumi Aksara.

3. Bahtiar. 2013. Potensi Pembelajaran yang Memadukan Strategi Think Pairs Share (TPS) dan Reading Questioning anf Answering (RQA) untuk Meningkatkan Sikap Sosial dan Penguasaan Konsep Biologi Siswa SMA Multietnis di Ternate. Seminar Nasional X Pendidikan Biologi FKIP UNS, 1-7.

4. Bahri, A. 2016. Strategi Pembelajaran Reading Questioning And Answering (RQA) Pada Perkuliahan Fisiologi Hewan Untuk Meningkatkan Hasil Belajar Kognitif Mahasiswa. Jurnal Bionature, Volume 17, Nomor 2, Oktober 2016, hlm. 106113.

5. Corebima, A.D. (2009). Pengalaman Berupaya Menjadi Guru Profesional, Pidato Pengukuhan Guru Besar Bidang genetika UM. Malang: Universitas Negeri Malang.

6. Darussyamsu, R dan Fadilah, M. 2017. Pengaruh Strategi Pembelajaran Reading, Questioning and Answering terhadap Kemampuan Berpikir Kreatif Mahasiswa Jurusan Biologi FMIPA Universitas Negeri Padang pada Matakuliah Evolusi. Bioeducation Journal. 1(1).

7. Gillen, J., Littleton, K., Twiner, A., Staarman, J. K., \& Mercer, N. 2008. Using the interactive whiteboard to resource continuity and support multimodal teaching in a primary science classroom. Journal of Computer Assisted Learning. 24 (4): 348 - 358. https://doi.org/10.1111/j.1365 - 2729.2007.00269.x.

8. Hasan, Adtman, A. 2019. Pengembangan media pembelajaran bahasa arab melalui aplikasi Videoscribe dalam meningkatkan motivasi belajar siswa. Jurnal Lisanuna. 9(2): 140-156.

9. Kocak, O., \& Gulcu, A. 2013. Teachers' remarks on interactive whiteboard with LCD panel technology. International Journal of Education in Mathematics Science and Technology. 1 (4), 294 - 300.

10. Manny Ikan, E., Dagan, O., Tikochinski, T. B., \& Zorman, R. 2011. Using the interactive white board in teaching and learning - An evaluation of the SMART CLASSROOM pilot project. Interdisciplinary Journal of E- Learning and Learning Objects. Vol 7.

11. Muslich, M. 2007. KTSP Pembelajaran Berbasis Kompetensi dan Konstektual. Jakarta: Bumi Aksara.

12. Najahaj. 2020. Inovasi pengembangan materi pelajaran bahasa asing tingkat madrasah tsanawiyah berbasis whiteboard animation. Jurnal Al'Adalah. 23(2). 163-177. Doi: https://doi.org/10.35719/aladalah.v23i2.34.

13. Plass, J. L., Heidig, S., Hayward, E. O., Homer, B. D., \& Um, E. 2014. Emotional design in multimedia learning: Effects of shape and color on affect and learning. Learning and Instruction, 29, 128-140.

14. Prasojo, Lantip Diat, dan Riyanto. 2011. Teknologi Informasi Pendidikan. Yogyakarta : Gava Media.

15. Pratiwi, et.al,. 2019. Pengembangan media pembelajaran fisika menggunakan sparkol videoscribe. Indonesian Journal of Science and Mathematics Education. 02 (3): 303-309.

16. Sadiman, Arief S., Raharjo., Anung, haryono., Rahardjito. (2009). Media Pendidikan. Jakarta: Raja Grafindo Persada.

17. Sakat, A. A., Mohd Zin, M. Z., Muhamad, R., Ahmad, A., Ahmad, H. A., dan Karno, M. A. 2012. "Educational Technologi Media Method in Teaching and Learning Progress". American Journal of Applied Sciences, 874-888.

18. Sardiman. 2011. Interaksi dan motivasi belajar mengajar. Jakarta: Rajawali Press.

19. Smaldino, S. E., et al. 2015. Instructional Technology and Media for Learning 11th Edition. Pearson: USA.

20. Tendrita, M. and Sari, A.P.P. 2020. Penerapan model pembelajaran kooperatif tipe Student Team Achievement Divisions (STAD) dipadu RQA berbasis lesson study untuk meningkatkan motivasi belajar dan kemampuan komunikasi mahasiswa pendidikan biologi universitas negeri malang. Bioedusiana. 5(1).1-10. http://jurnal.unsil.ac.id/index.php/bioed/index

21. Wibowo, Edy dan Matona, M.F. 2019. Pengembangan media pembelajaran berbasis whiteboard animation pada matakuliah trigonometri program studi pendidikan matematikan universitas Tompotika Luwuk. Jurnal Phytagoras. 8(2): 60-71.

Cite this Article: Dinia Anjelina, Violita (2022). Development of E-Learning with Whiteboard Animation Media Using Reading, Questioning Model and Answering (RQA) to Improve Learning Results and Student Motivation in the Department of Tadris Biology in IAIN Batusangkar. International Journal of Current Science Research and Review, 5(2), 594-600 